JURNAL PANGKAJA

PROGRAM PASCASARJANA

UNIVERSITAS HINDU NEGERI

I GUSTI BAGUS SUGRIWA DENPASAR
Vol.24, No. 2, September 2021

ISSN : 1412-7474 (Cetak)

ISSN : 2623-2510 (Online)

http://ejournal.ihdn.ac.id

\title{
KONSTRUKSI SOSIO-RELIGIUS UMAT HINDU DI BALI PADA MASA COVID-19
}

\author{
I Wayan Sukrayasa \\ Program Magister Brahma Widya \\ Universitas Hindu Negeri I Gusti Bagus Sugriwa Denpasar \\ E-mail: iwayansukrayasa283@gmail.com
}

\begin{abstract}
The social order and religious behavior in Indonesia, especially in Bali, have undergone many changes due to fluctuations in the Covid-19 pandemic. In addition to the impact on health, it also touches on the socio-religious behavior of Hindus in Bali. This religious perspective has a very strong influence in making people aware, especially Hindus in Bali, to take certain actions, including in dealing with the Covid-19 outbreak. This is also a very difficult challenge to the lives of Hindus, especially in Bali during this pandemic, namely when holding yajna ceremonies. Some changes in the behavior of Hindus are examples of the stages of outpouring or human self-expression into a world that is much different from the period before the Covid-19 pandemic. This has certainly rebuilt the social life and religiosity of Hindus in Bali during the Covid-19 pandemic. This article uses a qualitative approach by applying a descriptive analytical method. The construction process of behavior and social life of Hindus in Bali during the Covid-19 Pandemic, when viewed from the perspective of Berger \& Luckman's theory, took place through dialectical social interactions of three forms which became the entry concept, namely objective reality, symbolic reality and subjective reality. Regarding the Covid-19 pandemic situation, in terms of the religiosity of Hindus in Bali, the implementation of the yajna ritual should be carried out in a simple way, but still guided by the provisions of the Vedic scriptures.
\end{abstract}

Keywords: Socio-religious Construction, Yajna, Covid-19.

\begin{abstract}
ABSTRAK
Tatanan sosial dan perilaku keberagamaan di Indonesia khususnya di Bali mengalami banyak perubahan yang disebabkan oleh fluktuasi pandemi Covid-19. Selain dampak pada kesehatan, juga menyentuh pada perilaku sosio religius umat Hindu di Bali. Perspektif agama ini memiliki pengaruh sangat kuat dalam menyadarkan masyarakat khususnya umat Hindu di Bali untuk melakukan tindakan tertentu, termasuk dalam menghadapi wabah Covid-19 ini. Hal ini juga sebagai tantangan yang sangat berat pada kehidupan umat Hindu khususnya di Bali di masa pandemi ini yaitu pada saat menyelenggarakan upacara-upacara yajna. Beberapa perubahan perilaku umat Hindu adalah contoh tahapan pencurahan atau ekspresi diri manusia ke dalam dunia yang jauh berbeda dengan masa sebelum adanya pandemi Covid-19. Hal ini tentunya telah mengkontruksi kembali kehidupan sosial serta religiusitas umat Hindu di Bali selama masa Pandemi Covid-19. Artikel ini menggunakan pendekatan kualitatif dengan menerapkan metode deskriptif analitis. proses konstruksi perilaku serta kehidupan sosial umat Hindu di Bali selama masa Pandemi Covid-19, apabila dipandang dari perspektif teori Berger \& Luckman, berlangsung melalui interaksi sosial
\end{abstract}


dialektis dari tiga bentuk yang menjadi entry concept, yakni objective reality, symbolic reality serta subjective reality. Terkait situasi pandemi Covid-19, dalam aspek religiusitas umat Hindu di Bali, pelaksanaan ritual yajna seharusnya dilakukan dengan cara yang sederhana, namun tetap berpedoman pada ketentuan kitab suci Veda.

Kata Kunci: Konstruksi Sosio-religius, Yajna, Covid-19.

\section{PENDAHULUAN}

Menurut Budi Tri Akoso (2006:14) Pandemi adalah suatu peristiwa letupan dan penyebaran penyakit menular yang terjadi secara cepat dan melintas secara luas melewati batas Negara dan Benua. Berkaitan dengan itu virus Corona (Covid-19) yang kini telah menyebar ke berbagai negara di dunia, dan menginfeksi ribuan juta manusia hingga menimbulkan kematian sehingga virus ini dinyatakan Pandemi global.

Tatanan sosial dan perilaku keberagamaan di Indonesia khususnya di Bali mengalami banyak perubahan yang disebabkan oleh fluktuasi pandemi virus Corona (Covid-19) yang melanda hampir seluruh negara di dunia. Menurut Fakrur Razi dkk (2020: 07) virus Corona (Covid-19) merupakan penyakit baru yang dapat menyebabkan terjadinya gangguan pernafasan dan radang paru. Penyakit ini disebabkan oleh infeksi Severe Acute Respiratory Syndrome Coronavirus 2 (SAR-CoV-2).

Perubahan ini tidak hanya berdampak bagi kesehatan dan perekonomian, namun juga pada perilaku sosio religius masyarakat juga mengalami gelombang pasang, khususnya di kalangan umat Hindu di Bali. Selaras dengan yang dinyatakan oleh Murdiana (2021) bahwasanya dampak Virus Corona (Covid -19) terhadap kehidupan sosial budaya masyarakat Bali ini membuat munculnya kebudayaan baru, yang dimulai dari segi peraturan, segi kegiatan sosial dan segi kegiatan keagamaan.

Perhatian negara dan dunia terfokus pada penanganan pandemi yang besar dan meresahkan masyarakat ini. Berbagai kebijakan dikeluarkan dan anggaran besarpun dialokasikan untuk mengatasi dampak dari penyebaran Covid-19. Beberapa kebijakan yang dikeluarkan pemerintah Indonesia untuk menekan laju penyebaran virus Covid-19 di Indonesia seperti yang termuat dalam laman kompaspedia.kompas.id yaitu berawal dari PSBB, PSBB Transisi, PPKM Darurat hingga PPKM empat level yang bertujuan untuk memutus mata rantai penyebaran Covid-19 juga tidak luput dari pro-kontra masyarakat.

Covid-19 secara umum telah mengubah kebiasaan umat Hindu dalam melakukan bhaktinya pada Ida Sang Hyang Widhi Wasa/Tuhan Yang Maha Esa. Persembahyangan maupun yajna yang biasanya dilaksanakan secara massal telah ditiadakan. Hal ini juga telah diatur dalam terbitan Surat Edaran Menteri Agama Nomor 13 Tahun 2021 tentang Pembatasan Pelaksanaan Kegiatan Keagamaan di Rumah Ibadat untuk mencegah, mengendalikan, dan memutus mata-rantai penyebaran Covid-19 yang mengalami peningkatan di berbagai daerah dengan munculnya varian baru dan untuk memberikan rasa aman kepada masyarakat.

Masyarakat Hindu di Bali memiliki kehidupan keagamaan dan budaya yang inheren dengan kehidupan sehari-hari. Hal ini juga sebagai tantangan yang sangat berat pada kehidupan umat Hindu di masa pandemi ini pada saat menyelenggarakan upacara-upacara yajna. Pada pelaksanaanya, yajna yang kebanyakan melibatkan banyak orang, dalam waktu kini wajib dilaksanakan secara terbatas lantaran penyebaran Virus COVID-19. Berdasarkan hal tersebut tentunya dengan perkembangan fluktuatif Covid-19 telah banyak mengkonstruksi kembali kehidupan sosio-religus umat Himdu khususnya di Bali. 


\section{KAJIAN PUSTAKA}

Istilah konstruksi sosial atas realitas (sosial construction of reality) didefinisikan sebagai proses sosial melalui tindakan dan interaksi dimana individu menciptakan secara terus-menerus suatu realitas yang dimiliki dan dialami bersama secara subyektif. (Poloma, 2004:301). Asal usul konstruksi sosial dari filsafat Kontruktivisme yang dimulai dari gagasan-gagasan konstruktif kognitif. Menurut Von Glasersfeld, pengertian konstruktif kognitif muncul dalam tulisan Mark Baldwin yang secara luas diperdalam dan disebarkan oleh Jean Piaget. Namun apabila ditelusuri, sebenarnya gagasan pokok konstruktivisme sebenarnya telah dimulai oleh Giambatissta Vico, seorang epistemologi dari Italia, ia adalah cikal bakal Konstruktivisme (Suparno, 1997:24).

Konstruksi sosial sejatinya merupakan sebuah pemahaman kolektif mengenai sebuah konsep yang terbentuk dalam tatanan masyarakat. Banyak hal-hal yang dianggap lumrah dan masuk akal hari ini sebenarnya dibentuk, dikonstruksi, dan disepakati dalam ranah sosial pada masa tertentu, misalnya konsep uang, kewarganegaraan, atau seni. Seperti halnya kondisi pandemi Covid-19 yang melanda seluruh bagian dunia saat ini konsep social distancing terbentuk serta mengkonstruksi kebiasaan masyarakat di mana konsep social distancing memuat untuk mengurangi perkumpulan atau massa, sedangkan dalam pelaksanaan kegiatan keagamaan masyarakat Hindu Bali biasanya mengundang umat untuk bersama-sama, bergotong royong.

Sebuah artikel yang berjudul "Konstruksi Sosial Keagamaan Masyarakat pada Masa Pandemi Covid-19" yang ditulis oleh Ghofur (2020:299) menyatakan bahwasanya konstruksi sosial keagamaan perspektif tasawuf pada masa pandemi dari sisi teologis diyakini bahwa Tuhan sedang menguji hambanya melalui mahluknya berupa Covid-19. Lebih lanjut terkait konstruksi sosial keagamaan perspektif tasawuf pada masa pandemi mengasilkan pola perilaku agama: sabar, syukur, tawakal dan muhasabah.

Artikel tersebut menyatakan bahwasanya konstruksi sosial keagamaan menurut pandangan tasawuf bagi umat Islam yaitu menghasilkan perilaku agama yang lebih berdampak pada diri sendiri yaitu seperti rasa sabar, rasa bersyukur, tawakal, serta muhasabah. Pada artikel ini akan dibahas lebih lanjut mengenai konstruksi sosio religius umat Hindu pada masa pandemi Covid-19 yang juga banyak memunculkan perubahanperubahan pada aktivitas sosial serta religiusitas umat Hindu.

\section{METODE}

Metode pada sebuah karya ilmiah memegang peranan penting guna mendapatkan data yang objektif, valid dan selanjutnya digunakan untuk memecahkan permasalahan yang telah dirumuskan. Begitu pula dalam artikel ini, menggunakan pendekatan kualitatif dengan menerapkan metode deskriptif analitis. Artikel ini bertujuan untuk membuat gambaran secara sistematis, faktual dan akurat mengenai fakta-fakta dan sifat-sifat pada objek. Data dikumpulkan dengan teknik studi literatur, yang kemudian dilakukan analisis dengan menggunakan pendekatan dan teknik analisis kualitatif yang disajikan dalam pembahasan.

\section{PEMBAHASAN}

1. Konstruksi Sosial Umat Hindu di Bali pada Masa Covid-19

Proses konstruksi perilaku serta kehidupan sosial umat Hindu di Bali selama masa Pandemi Covid-19, apabila dipandang dari perspektif teori Berger \& Luckman, berlangsung melalui interaksi sosial dialektis dari tiga bentuk yang menjadi entry concept, yakni objective reality, symbolic reality serta subjective reality. Selain itu, konstruksi juga berlangsung dalam suatu proses dengan tiga simultan: eksternalisasi, objektivasi dan internalisasi. 
a. Objective reality adalah suatu kompleksitas definisi realitas serta rutinitas tindakan dan tingkah laku yang telah mapan terpola, yang kesemuanya dihayati oleh individu secara umum sebagai fakta.

b. Symblolic reality merupakan semua ekspresi simbolik dari apa yang dihayati sebagai "objective reality", misalnya teks produk industri media, seperti berita di media cetak atau elektronika, begitu pun yang ada di film-film.

c. Subjective reality adalah konstruksi definisi realitas yang dimiliki individu, kemudian dikonstruksi melalui proses internalisasi. Realitas subyektif yang dimiliki masing-masing individu merupakan basis untuk melibatkan diri dalam proses eksternalisasi. (Dedy, 2003)

Bungin (2008:193) menyatakan bahwa melalui sentuhan Hegel yakni tesis-antitesissintesis, Berger menemukan konsep untuk menghubungkan antara yang subyektif dan obyektif melalui konsep dialektika, yang dikenal dengan eksternalisasi- objektivasiinternalisasi.

a. Eksternalisasi adalah penyesuaian diri dengan dunia sosio-kultural sebagai produk manusia. "Society is a human product".

Eksternalisasi merupakan usaha pencurahan atau ekspresi diri manusia ke dalam dunia, baik dalam kegiatan mental maupun fisik. Ini sudah menjadi sifat dasar manusia, selalu mencurahkan diri ke tempat dimana Ia berada. Manusia tidak dapat mengerti sebagai ketertutupan yang lepas dari dunia luarnya. Manusia berusaha menangkap dirinya kemudian dihasilkan suatu dunia. Dengan kata lain, manusia menemukan dirinya sendiri dalam suatu dunia.

Penyesuaian diri dengan dunia sosio-kultural pada masyarakat "Society is a human product" selaras dengan pemaparan Ahli Medis Combiphar Sandi Perutama Gani yang menyatakan bahwa covid-19 tidak selalu membawa dampak negatif secara sosiobiologis. Ia berpendapat bahwa ada beberapa hal positif yang bisa didapat oleh masyarakat. (Online: https://www.liputan6.com/health/read/4258205/perubahanperilaku-masyarakat-yang-terjadi-selama-pandemi-covid-19-di-indonesia).

Tahap eksternalisasi masyarakat juga selaras dengan hasil survei dari McKinsey, yang menyakan bahwa Covid-19 membawa kekhawatiran bagi masyarakat. Kekhawatiran terbesar, dengan angka 62\%, adalah tidak mengetahui berapa lama kondisi ini akan berlangsung. Ini disusul dengan kekhawatiran akan keselamatan diri dan keluarga $(61 \%)$, Serta kekhawatiran akan kontribusi dalam penyebaran virus sebesar $45 \%$. Adapun dampak dari kekhawatiran tersebut adalah perubahan perilaku masyarakat menjadi lebih peduli akan kebersihan dan kesehatan, di kalangan menengah atas hingga menengah ke bawah. Dilihat dari hasil survei, 85\% masyarakat lebih memerhatikan kebersihan tangan, 55\% lebih sering mengonsumsi air putih. Lebih lanjut, 47\% lebih banyak mengonsumsi sayur dan buah, dan 18\% lebih sering berolahraga. (Ghofur, 2020:291)

Beberapa perubahan perilaku tersebut adalah contoh tahapan eksternalisasi masyarakat dalam pencurahan atau ekspresi diri manusia ke dalam dunia yang jauh berbeda dengan masa sebelum adanya pandemi Covid-19. Hal ini tentunya telah menjadi sifat dasar manusia, yang senantiasa mencurahkan diri ke tempat dimana berada dengan selalu beradaptasi.

b. Objektivasi adalah interaksi sosial dalam dunia intersubyektif yang dilembagakan atau mengalami institusionalisasi. "Society is an objective reality".

Objektivasi merupakan hasil yang telah dicapai, baik mental maupun fisik dari kegiatan eksternalisasi manusia tersebut. Hasil itu menghasilkan realitas obyektif yang 
bisa jadi akan menghadapi penghasil itu sendiri sebagai suatu faktisitas yang berada di luar dan berlainan dari manusia yang menghasilkannya. Proses objektivasi adalah interaksi sosial dalam dunia intersubyektif yang dilembagakan atau mengalami institusionalisasi. "Society is an objective reality" tidak terlepas dari konflik sosial hingga terbentuknya subjektifitas dalam kondisi yang tidak menentu di masa pandemi seperti ini. (Bungin, 2008:193)

Proses objektivasi terlebih dahulu dijalani oleh kalangan penggerak ekonomi, yakni sejumlah produsen masker yang menyadari dampak pandemi ini. Jumlah produsen masker meningkat drastis selama pandemic covid-19 di Indonesia. Kementerian Kesehatan mencatat angkanya melonjak hingga 200\%. Direktur Jenderal Kefarmasian dan Alat Kesehatan (Dirjen Farmalkes) Kementerian Kesehatan (Kemenkes), Engko Sosialine Magdalene, menjelaskan bahwa sebelum wabah virus Covid-19, jumlah produsen masker hanya 26 dan kini yang sudah mendapatkan izin menjadi 83 produsen. Perizinan sudah diberikan dan bila pada awal tahun hanya ada 26 produsen masker, Saat ini jumlahnya mencapai 83 produsen. Artinya, terdapat peningkatan lebih dari $200 \%$, yang diketahui melalui data perizinan untuk produsen masker. (Online: https://finance.detik.com/industri/d-5003092/produsen-maskermelonjak-200-di-tengah-pandemi-corona).

Darmayasa (2014: 86) dalam bukunya yang berjudul Canakya Niti Sastra menguraikan bahwa untuk menjaga eksistensi manusia dharma dalam mempertahankan hidup terlebih lagi pada peliknya perkembangan pandemic Covid-19, dapat terpetik hikmahnya dari sloka Canakya Nitisastra XVI.18 yang menyatakan untuk membangun hidup sejahtera maka manusia harus eksistensikan lima hal secara benar, baik, dan tepat. Lima hal tersebut diantaranya: dharma (agama), dhanam (asset), dhanyam (bahan makanan), subha cita (kata bijak), dan ausada (kesehatan).

Jadi, dhanam atau asset kekayaan/uang/harta benda serta makanan harus tetap diperoleh dengan dasar dharma walaupun berada pada titik kesusahan di masa pandemic Covid-19. Dhanyam dimaksudkan untuk menjaga kualitas makanan agar terbebas dari virus, dan ausada menjaga kesehatan mental serta fisik dengan cara berolah raga.

c. Internalisasi adalah individu mengidentifikasi diri di tengah lembaga- lembaga sosial, di mana individu tersebut menjadi anggotanya. "Man is a sosial product".

Menurut Bungin (2008:193) dalam bukunya yang berjudul Sosiologi Komunikasi, menguraikan bahwa proses internalisasi lebih bermakna penyerapan kembali dunia obyektif ke dalam kesadaran sedemikian rupa hingga subyektif individu dipengaruhi oleh struktur dunia sosial. Berbagai macam unsur dari dunia yang telah terobyektifkan tersebut ditangkap sebagai gejala realitas di luar kesadarannya, sekaligus sebagai gejala internal untuk kesadaran. Melalui internalisasi, manusia menjadi hasil dari masyarakat.

Sebagaimana yang terjadi saat ini, internalisasi umat Hindu di Bali telah mengalami perubahan signifikan. Terlepas dari kenyataan bahwa kebanyakan orang dikurung di rumah, banyak juga yang tidak pernah merasa lebih dekat dengan keluarga daripada sekarang. Kemudian, kegiatan gotong royong di Bali seperti ngayah yaitu aktivitas goting royong saling membantu antar umat yang melibatkan banyak orang juga dengan adanya situasi pandemic Covid-19 dengan berat hati harus ditiadakan. Upacara-upacara yajna yang melibatkan banyak orang juga dibatasi pelaksanaannya.

2. Religiusitas Umat Hindu dalam Melaksanakan Yajna pada Masa Pandemi Covid-19

Secara teologis perlu kiranya diyakini bahwa Tuhan/Ida Sang Hyang Widhi Wasa sedang menguji dengan memberikan cobaan pada umatnya melalui pandemic Covid-19 ini. Juniartha (2020:191-192) menyatakan bahwa bahasan mengenai kemunculan 
wabah-wabah penyakit juga telah tertuang dalam berbagai pustaka suci Hindu. Salah satu pustaka menyebutkan bahwa munculnya wabah penyakit adalah salah satu ciri dari pada jaman kali yuga yang juga disebut dengan jaman kegelapan. Seperti yang tersurat dalam Lontar Widhisastra Roga Sanggara Bhumi, yang menyuratkan:

“...ritatkalaning ganti kali bhumi, gering sasab marana tan pegat, ngendah laraning wwang, gumigil panas uyang, akweh pejah, tepi ning tasik tembening agerin, mantra usada punah. Pandhita bingung, Weda mantra tan pasari."

Terjemahannya:

"...tatkala pergantian Bumi Kali yuga, penyakit menular mewabah (gering-sasabmarana) tidak bisa dihentikan, tidak terbatas derita manusia, menggigil panas uyang (kehilangan kesabaran dilanda cemas), banyak korban meninggal, desa-desa pesisir (perbatasan) ketiban penyakit, mantra pengobatan punah. Pandita bingung, Weda mantra kehilangan sari (esensi kekuatan/daya magis)."

Melakukan kegiatan yajna memang merupakan perintah agama dan merupakan wujud pengamalan sraddha atau dasar keyakinan. Yajna juga wujud bhakti umat Hindu kepada Sang Maha Pencipta. Kegiatan ritual yajna sangat beragam sesuai tradisi atau budaya keagamaan yang berkembang dan dianut komunitas masyarakat khususnya umat Hindu di Bali. Karena itu, tradisi tersebut bukan harga mati. Ia dapat berubah sesuai tuntutan aktual yang di hadapinya.

Umat Hindu juga mengenal adagium "desa, kala, patra, dan desa mawa acara". Hal ini dibenarkan menurut susastra Veda, seperti dinyatakan dalam Manawa Dharmasastra VII. 10 (Pudja, 1995:707) yang berbunyi:

"Karyam so'weksya saktinca. Desa kalanca tattwatah. Kurute dharmasiddhyar tham. Wiswarupam punah-punah."

Terjemahannya:

"Setelah mempertimbangkan aspek: Iksa, Sakti, Desa, Kala, dan Tattwa, ia wujudkan/tetapkan berbagai kebijakan untuk mencapai tujuan yang sempurna.

Iksa adalah hakikat tujuan melakukan kegiatan. Hal ini dikaitkan dengan tujuan pelaksanaan yajna. Sakti, adalah kemampuan fisik/finansial dan jarang dikaitkan dengan seremonial dan ritualnya. Desa, adalah lokasi tempat kegiatan. Ini dikaitkan dengan kemungkinan tata cara yang paling sesuai dengan keadaan lingkungan. Sementara Kala adalah waktu/era/zaman. Ini dikaitkan dengan budaya yang berkembang di masyarakat. Adapun Tattwa, adalah hakikat ajaran atau nilai filosofis yang dijadikan dasar utama untuk menguji mengenai tata cara atau tradisi yang berjalan selama ini tidak menyimpang dari ajaran Veda.

Pengkajian atas kelima hal di atas hendaknya berpedoman pada ajaran Tri Pramana, yaitu: agama pramana (ketentuan susastra agama), anumana pramana (menganalisis menggunakan logika), serta pratyaksa pramana (melihat secara eksklusif fenomena di lapangan). Nilai yajna itu bukan hanya dipengaruhi oleh besar kecilnya upakara atau persembahan ritual. Nilai yajna sangat dipengaruhi oleh tingkat keyakinan/sraddha pelaku (sang Yajamana), kekuatan spiritual Pandita/Pinandita yang memimpin upacara (Manggala Upacara), dan kejernihan hati pembuat sesaji/upakara (Sarati Banten). Kemudian, kunci keberhasilan Yajna lainnya merupakan sifat ketulusikhlasan (sifat lascarya) dari para manggala yajna, dan jauh dari perilaku pamer atau jor-joran (nasmita).

Istilah desa, kala, patra yang tersurat secara berurutan dalam bahasa aslinya terdapat dalam kitab Bhagawad Gita, sloka 17. 20 yang berbunyi sebagai berikut (Mantra, 2017: 231). 
"dātavyam iti yad dānam dìyate "nupakārine

deśe kāle ca pātre ca tad dānaì sāttvikam smrtam"

Terjemahan:

"Pemberian, dana, yang dilakukan pada seorang tanpa harapan kembalinya, dengan perasaan bahwa adalah kewajiban seorang untuk memberi serta diberikan pada tempat yang baik dan pada orang yang patut, dana itu disebut sattwika, baik.

Terjemahan sloka tersebut dapat diartikan sebagai sebuah pedoman singkat dalam berderma, yaitu kedermawanan yang diberikan karena kewajiban, tanpa mengharapkan pamrih, pada waktudan tempat yang tepat, kepada orang yang patut menerimanya dianggap kebaikan.

Terkait situasi pandemi Covid-19, pelaksanaan ritual yajna seharusnya dilakukan dengan cara yang sederhana, namun tetap berpedoman pada ketentuan kitab suci Veda, baik Sruti, Smerti maupun Nibandhasastra. Antara tattwa, susila dan acara sangat penting diperhatikan dalam pelaksanaan ritual yajna. Oleh karena itu, ritual yajna harus memenuhi aspek Tattwa (yang mengandung nilai-nilai filosofis), ditawarkan secara etis dan memiliki rasa pengabdian yang tulus (aspek moral).

Pelaksanaan yajna dalam Hindu dilaksanakan atas dasar hati yang tulus dan ikhlas. Ida Sang Hyang Widhi Wasa memiliki kekuatan Cadu Sakti sebab, Dia sesungguhnya mengisi segala ciptaan secara gaib dan menggerakkannya, menjadi raja dari sekalian makhluk, sekaligus sebagai saksi dalam setiap pikiran. Menurut Brahman (2017:11) Cadu sakti adalah empat kekuatan atau kemahakuasaan Tuhan. Cadu sakti terdiri dari: 1) Wibhusakti yaitu kemahakuasaan Tuhan yang mampu meresapi segalanya. Tuhan ada di setiap ciptaanNya; bahwa segala sesuatu yang ada di alam semesta ini diresapi oleh Tuhan. 2) Prabusakti yaitu kemahakuasaan Tuhan yang menguasi segala-galanya. Tuhan adalah penguasa atas segalanya, segala yang ada; ada di bawah kuasaNya. 3) Jnanasakti yaitu kemahakuasaan Tuhan yang mampu mengetahui segalanya. Tuhan adalah maha tahu, segala pengetahuan ada padaNya. Beliau adalah sumber dari segala sumber pengetahuan. 4) Kriyasakti yaitu kemahakuasaan Tuhan yang maha kriya atau Tuhan yang memiliki kekuasaan atas segala tindakan/kerja atau perbuatan apa saja. Segala sesuatu di semesta ini adalah hasil karya dari Tuhan, dan segala sesuatu yang terjadi adalah hasil karyaNya.

Dengan demikian, sebagai makhluk ciptaan-Nya tidak mungkin menyembunyikan diri dengan berpura-pura, apalagi berdusta. Sebab, Hyang Widhi Wasa adalah saksi abadi yang tak terjamah oleh noda dan pengaruh apapun yang bersifat maya.

Dapat dipahami bahwa yajna bukanlah dilakukan dalam bentuk ritual semata, melainkan harus diikuti dengan pemberian derma (danam) kepada orang-orang yang memerlukan. Derma itu pun harus disertai dengan pengedalian diri (tapah) sehingga apa yang kita persembahkan akan bermanfaat bagi kemanusiaan. Hal mengenai yajna tertuang dalam susastra Bhagavad Gita (Mantra, 2017:236) yang menyatakan bahwa:

"yajñadānatapaḥkarma na tyājyam kāryameva tat,

yajño dānam tapaścaiva pāvanāni manīṣinām."

Terjemahan:

"Perbuatan korban suci, kedermawanan dan pertapaan tidak boleh ditinggalkan; kegiatan itu harus dilakukan. Roh-roh yang mulia sekalipun disucikan oleh korban suci, kedermawanan dan pertapaan"

(Bhagawadgita, XVIII.5)

Yajna sebagai upaya mengubah energi negatif menjadi positif. Yajna berubah dari rajasika yajna (jor-joran) menjadi satwika yajna yang mengetengahkan pada keutamaan 
yajna. Berpedoman pada ini, ternyata pandemi menjadi penyeimbang kesadaran dan penguatan keyakinan umat sesungguhnya. Yajna adalah pertimbangan atas konsep Wahya Dyatmika. Artinya, jika menuju yang niskala dengan cara baik, maka sekalanya dulu mesti baik.

Pandemi mengisyaratkan bahwa manusia semestinya memulai dari kesadaran akan pentingnya segala isi alam untuk kepentingan yajna. Jika dicermati, pelaksanaan yajna di saat pandemi khususnya di Bali berlangsung dengan pengurangan waktu. Namun, tidak berarti kualitas yajna menurun. Kualitas yajna sesuai dengan dasar keyakinan bahwa yajna sebagai salah satu upaya bernegosiasi dengan alam sehingga sampai pada point yajna memuliakan itu memuliakan alam.

\section{KESIMPULAN}

Berdasarkan pembahasan tersebut diatas, dapat disimpulkan bahwa proses konstruksi perilaku serta kehidupan sosial umat Hindu di Bali selama masa Pandemi Covid-19, apabila dipandang dari perspektif teori Berger \& Luckman, berlangsung melalui interaksi sosial dialektis dari tiga bentuk yang menjadi entry concept, yakni objective reality (suatu kompleksitas definisi realitas serta rutinitas tindakan dan tingkah laku yang telah mapan terpola, yang kesemuanya dihayati oleh individu secara umum sebagai fakta), symbolic reality (semua ekspresi simbolik dari apa yang dihayati sebagai "objective reality") serta subjective reality (konstruksi definisi realitas yang dimiliki individu, kemudian dikonstruksi melalui proses internalisasi).

Terkait situasi pandemi Covid-19, dalam aspek religiusitas umat Hindu di Bali, pelaksanaan ritual yajna seharusnya dilakukan dengan cara yang sederhana, namun tetap berpedoman pada ketentuan kitab suci Veda, baik Sruti, Smerti maupun Nibandhasastra. Antara tattwa, susila dan acara sangat penting diperhatikan dalam pelaksanaan ritual yajna. Oleh karena itu, ritual yajna harus memenuhi aspek Tattwa (yang mengandung nilai-nilai filosofis), ditawarkan secara etis dan memiliki rasa pengabdian yang tulus (aspek moral).

\section{DAFTAR PUSTAKA}

Akoso, Budi Tri, 2006. Waspada Flu Burung: Penyakit Menular pada hewan dan manusia. Yogyakarta: Kanisius.

Ansori, Ade Nasihudin Al. Perubahan Perilaku Masyarakat yang Terjadi Selama Pandemi COVID-19 di Indonesia. Tersedia dalam: https://www.liputan6.com/health/read/4258205/perubahan-perilaku-masyarakatyang-terjadi-selama-pandemi-covid-19-di-indonesia, diakses tanggal 18/07/2021.

Brahman, I Made Adi. 2017. Korelasi Ajaran Cadu Sakti Dengan Catur Yoga. Vidya Samhita: Jurnal Penelitian Agama, 3(2), 9-25.

Bungin, H.M Burhan. 2008. Sosiologi Komunikasi: Teori Paradigm dan Diskursus Teknologi Komunikasi di Masyarakat. Jakarta: Prenada Media Grup.

Darmayasa, I Made. 2014. Canakya Niti Sastra. Surabaya : Paramita.

Dedy N Hidayat, Konstruksi Sosial Industri Penyiaran : Kerangka Teori Mengamati Pertarungan di Sektor Penyiaran, Makalah dalam diskusi "UU Penyiaran, KPI dan Kebebasan Pers, di Salemba 8 Maret 2003. Tersedia dalam: https://www.google.com/url?sa=t\&rct=j\&q=\&esrc=s\&source=web\&cd=\&ved=2ah UKEwiU58Se0vbxAhUU8XMBHSTLAPYQFjAAegQIAhAD\&url=http\%3A\%2F \%2Fjournal.unair.ac.id\%2Fdownload-fullpapersJURNAL\%2520ANDREAS.doc\&usg=AOvVaw3GaTW2LCdBsfEO2LjTpO_Y, diakses tanggal 15/07/2021.

Ghofur, Abdul. 2020. Konstruksi Sosial Keagamaan Masyarakat pada Masa Pandemi Covid19. Jurnal Dakwah dan Komunikasi Islam, 6(2), 281-301. 
Juniartha, M.G, \& PASK Dewi. 2020. Yoga Virtual Sebagai Metode Dharma Sadhana Guna Meningkatkan Kesehatan Spiritual Masyarakat di Tengah Masa Pandemi Covid-19. Maha Widya Duta: Jurnal Penerangan Agama, Pariwisata Budaya, dan Ilmu Komunikasi, 4(2), 191-200.

Keputusan Menteri Kesehatan Republik Indonesia Nomor Hk.01.07/Menkes/382/2020 tentang Protokol Kesehatan Bagi Masyarakat Di Tempat Dan Fasilitas Umum Dalam Rangka Pencegahan Dan Pengendalian Corona Virus Disease 2019 (Covid-19)

Keputusan Presiden Republik Indonesia Nomor 12 Tahun 2020 tentang Penetapan Bencana Non alam Penyebaran Corona Virus Disease 2019 (Covid-19) Sebagai Bencana Nasional

Mantra, I.B. 2017. Bhagawadgita (Alih Bahasa dan Penjelasan). Badung: Dinas Kebudayaan Kabupaten Badung.

Murdiana, I Ketut Agus. 2021. Dampak Virus Corona (Covid-19) Terhadap Kehidupan Sosial Budaya Masyarakat Hindu Bali (Perspektif Pendidikan Agama Hindu). JAPAM: Jurnal Pendidikan Agama, 1(1), 32-43.

Poloma, Margareth. 2004. "Sosiologi Kontemporer". PT.Raja Grafindo Persada, Jakarta.

Pudja, Gde, dan Tjokorda Rai Sudharta. (1995). Manawa Dharmasastra (Manu Dharma Sastra). Jakarta: Hanuman Sakti.

Razi, H. F, Dkk. (2020). Bunga Rampai Covid-19 : Buku Kesehatan Mandiri Untuk Sahabat \#Dirumahaja. Depok : Pd Prokami Kota Depok.

Subagia, I Wayan, \& Wiratma, I Gusti Lanang. 2009. 89 Evaluasi Penerapan Model Siklus Belajar Berbasis Tri Pramana pada Pembelajaran Kimia di Sma. Jurnal Pendidikan dan Pengajaran, 42(2), 89-96.

Suparno. 1997. "Filsafat Konstruktivisme dalam Pendidikan”. Yogyakarta: Kanisius.

Sumber Internet:

https://kompaspedia.kompas.id/baca/infografik/kronologi/kebijakan-covid-19-dari-psbbhingga-ppkm-empat-level, diakses tanggal 27/09/2021.

https://regional.kompas.com/read/2020/05/04/18453001/ngaben-saat-wabah-covid-19seorang-warga-ditetapkan-tersangka, diakses tanggal 27/09/2021.

https://finance.detik.com/industri/d-5003092/produsen-masker- melonjak-200-di-tengahpandemi-corona, diakses tanggal 27/09/2021. 